\title{
Removal of Volatile Organic Compounds by Means of a Felt-Based Living Wall Using Different Plant Species
}

\author{
Gina Patricia Suárez-Cáceres (D) and Luis Pérez-Urrestarazu *(D) \\ Urban Greening and Biosystems Engineering Research Group, ETSIA, Universidad de Sevilla, \\ 41013 Seville, Spain; gscaceres@us.es \\ * Correspondence: lperez@us.es; Tel.: +34-95-448-6420
}

Citation: Suárez-Cáceres, G.P.;

Pérez-Urrestarazu, L. Removal of Volatile Organic Compounds by Means of a Felt-Based Living Wall Using Different Plant Species.

Sustainability 2021, 13, 6393

https://doi.org/10.3390/su13116393

Academic Editor:

Giouli Mihalakakou

Received: 17 May 2021

Accepted: 2 June 2021

Published: 4 June 2021

Publisher's Note: MDPI stays neutral with regard to jurisdictional claims in published maps and institutional affiliations.

Copyright: (c) 2021 by the authors. Licensee MDPI, Basel, Switzerland. This article is an open access article distributed under the terms and conditions of the Creative Commons Attribution (CC BY) license (https:// creativecommons.org/licenses/by/ $4.0 /)$.

\begin{abstract}
Poor indoor quality affects people's health and well-being. Phytoremediation is one way in which this problem can be tackled, with living walls being a viable option for places with limited space. The aim of this study was to evaluate the efficiency of five plant species in a living wall to remove Volatile Organic Compounds (VOCs) and to identify whether the type of pollutant has any influence. An enclosed chamber was used to add the contaminants n-hexane and formaldehyde independently. Total VOCs were measured for three days in two scenarios: (1) empty chamber, and (2) chamber with living wall. Five living walls were prepared, each with three plants of the same species: Spathiphyllum wallisii, Philodendron hederaceum, Ficus pumila, Tradescantia pallida, and Chlorophytum comosum. There was no correlation between leaf area/fresh weight/dry weight and the contaminant reduction. In general, all five species were more efficient in reducing TVOCs when exposed to formaldehyde than to $n$-hexane. Chlorophytum comosum was the most efficient species in reducing the concentration of TVOCs for both contaminants, Spathiphyllum wallisii being the least efficient by far.
\end{abstract}

Keywords: green wall; indoor air quality; TVOCs; Spathiphyllum wallisii; Philodendron hederaceum; Ficus pumila; Tradescantia pallida; Chlorophytum comosum

\section{Introduction}

People tend to spend most of their time indoors [1]. For that reason, maintaining an adequate Indoor Air Quality (IAQ) is essential, as poor levels can affect people's health (Sick Building Syndrome) [2]. Buildings are now increasingly being constructed in an airtight manner in order to maximise their energy efficiency [3], preventing adequate ventilation of indoor spaces [4]. IAQ can be affected by polluted air coming from outside the building, but there are also many indoor contaminants [5].

Volatile Organic Compounds (VOC) are mostly anthropogenic contaminants with known effects on health, going from irritation of the eyes and respiratory tract to more serious illnesses such as liver and kidney damage or cancer [6]. VOCs are widely emitted from products commonly used in construction (e.g., paints, solvents, varnishes, etc.) and many others employed on a day-to-day basis (detergents, products, air fresheners, cleaning, and personal care products, etc.) [7].

Formaldehyde is one of the most common indoor VOCs [8-10] because it originates from indoor sources in composite wood products [11]. Another common contaminant is n-hexane, which is classified as an alkane [12] and has adverse effects on the central nervous system [13] but has been less researched as an indoor contaminant.

There are many different methods proposed to improve IAQ. One of them is the use of plants, known as phytoremediation [14], which offers a solution to the energy consumption of other air purification technologies. Its efficiency depends on many different factors such as the type of system, which can be passive (potted plants) or active (filter plants, activated carbon) [15], temperature, light intensity, growing media, or VOC (identity, concentration, 
potential mixture effects) [16]. However, the type of plant or species used seems to be one of the main key factors influencing VOC removal efficiency [17].

There is often limited space indoors to provide the amount of vegetation needed to improve air quality. Thus, living walls can be considered as a viable solution [18]. They also contribute to improving the aesthetical component and offer psychological benefits associated with indoor vegetation [19]. In fact, some studies [20] point to living walls being more efficient than potted plants in removing indoor contaminants.

The aim of this work was to evaluate the efficiency of five species planted in living wall modules to remove VOCs for IAQ improvement and to assess if the type of contaminant had any influence.

\section{Materials and Methods}

\subsection{Preparations of the Tests and Environmental Conditions}

A sealed glass chamber ( $0.8 \mathrm{~m}$ long; $0.4 \mathrm{~m}$ wide; $0.4 \mathrm{~m}$ high) [19] was used where contaminants were released in two scenarios: with the chamber empty and with a small living wall inside (Figure 1).

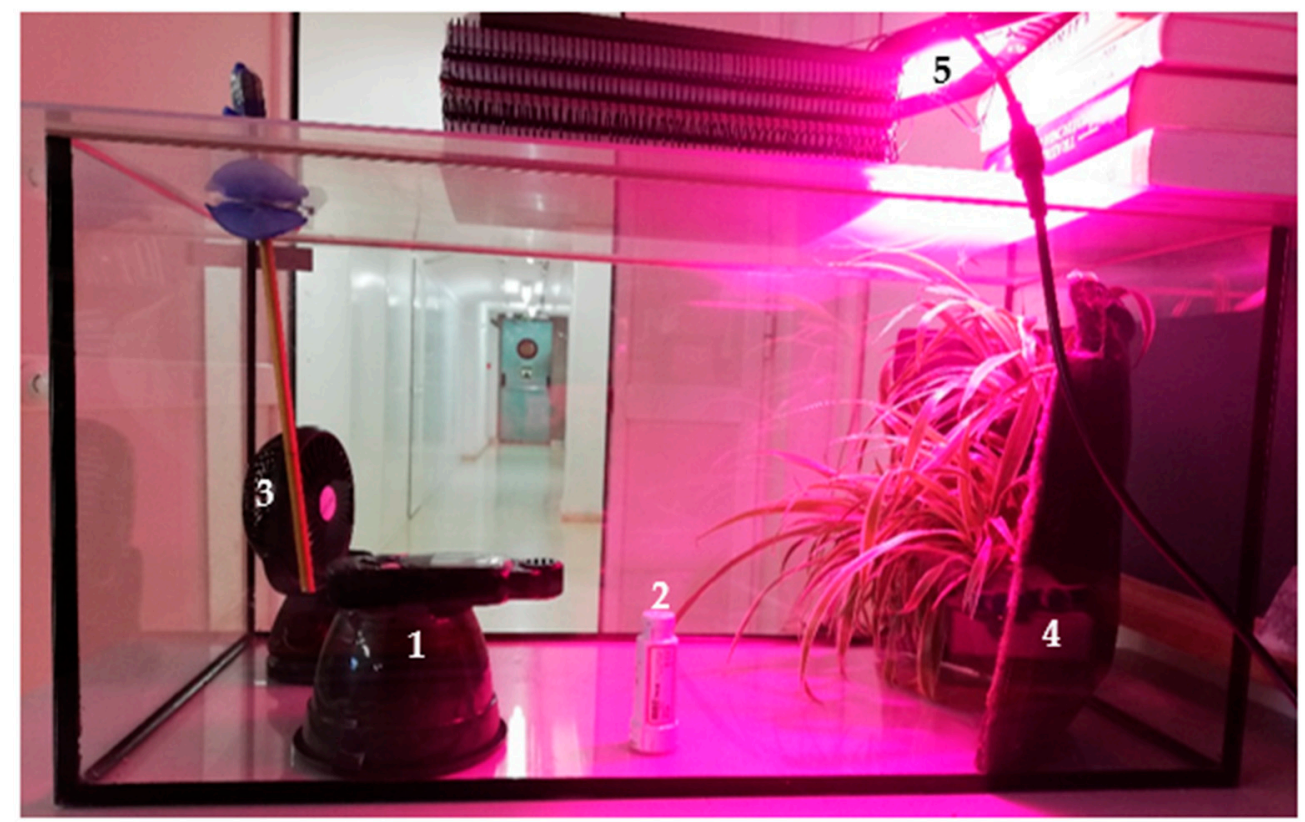

Figure 1. Sealed glass chamber where n-hexane and formaldehyde tests were performed for each plant species. (1) Gas detector; (2). HOBO sensor; (3) Portable fan; (4) Felt-based module with three plants per species; (5) Grow photosynthetic lamp.

The living walls used for the tests consisted of a felt-based module (Fytotextile ${ }^{\circledR}$, Terapia Urbana, S.L., Seville, Spain) [21], $0.49 \mathrm{~m}$ wide by $0.36 \mathrm{~m}$ high. The inner geotextile layer was sawn to the exterior polyamide layer forming a grid of 2 by 3 pockets. Finally, a waterproof layer was added at the back of the living wall module in order to mimic the exact configuration of the commercial system (Figure 2). The air temperature inside the chamber was monitored by a HOBO Pro Temp-HR U23-001 sensor (Onset Computer Corp., Bourne, MA, USA). The temperature range in which the tests were carried out was $15.7^{\circ} \mathrm{C}$ to $26.8^{\circ} \mathrm{C}$.

Inside the chamber, the air was mixed by means of a small portable fan to achieve a uniform distribution of the contaminant. A CF-UT01 LED Grow photosynthetic lamp (Panda Grow, Shenzhen, China) with a light cycle of $15 \mathrm{~h}$ was used, positioned right on the chamber at an angle of $14^{\circ}$ to the vegetation with respect to the horizontal position and with an average illuminance of 6828 Lux [19]. 


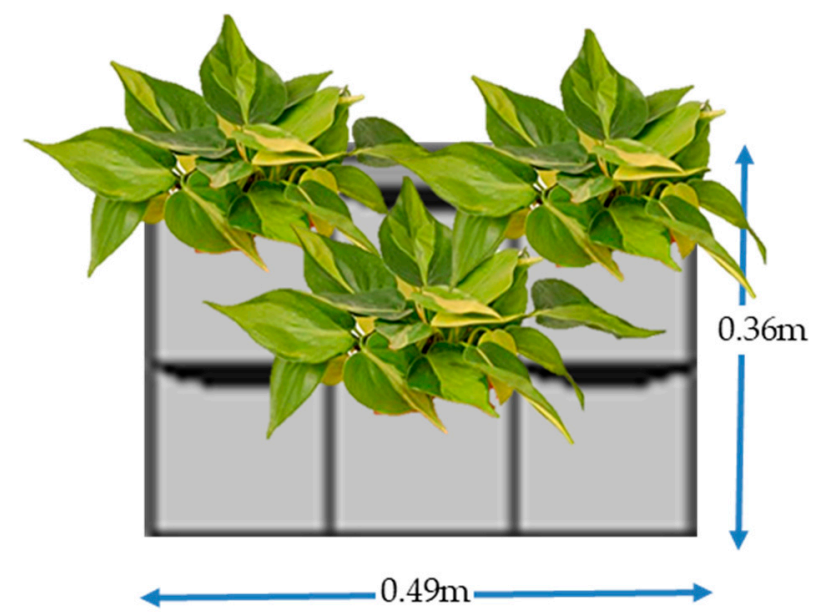

Figure 2. Felt-based module design and distribution of the three plants for each species.

\subsection{Selected Plants}

Five small modules were prepared specifically for the tests, each planted with a different species:

1. Spathiphyllum wallisii is commonly used as an ornamental houseplant due to its availability. It can withstand poor growing conditions [22] and its ability to capture atmospheric particles has been studied [23].

2. Philodendron hederaceum is an ornamental foliage climber plant commonly used in indoor environments. It has the potential to absorb harmful gases and clean the air inside buildings [24].

3. Ficus pumila tolerates shade very well [25] and is an ornamental plant that has been frequently used in green walls [26]. There are not many studies regarding its potential to improve indoor air quality.

4. Tradescantia pallida is a plant found in gardens and public spaces such as squares and roadsides [27] and it has shown efficiency in the removal of benzene, toluene, TCE, and $\alpha$-pinene [28].

5. Chlorophytum comosum is one of the most studied plants for phytoremediation of indoor air contaminants $[15,29]$ and uses formaldehyde as a source of energy for biosynthesis [30].

Three plants per species were planted in each module and maintained for two months prior to the tests to ensure full root development through the living wall felt. Two plants were placed in the lower row and one in the middle pocket of the upper row (Figure 2), by inserting inside the pocket the root ball with a Seed Pro 7030 substrate (Projar professional, Projar, Valencia, Spain) to favour the rooting of the plant.

\subsection{Test Procedure and Data Collection}

Two different organic compounds were used as sources of contaminants: n-hexane and formaldehyde. In order to assess the VOC removal potential of each species, the Total Volatile Organic Compounds (TVOCs) [31] levels were monitored by means of a PCE-VOC 1 gas detector (PCE Ibérica S.L., Albacete, Spain) [19].

A first test was carried out with the chamber empty (scenario one), to record the mean value of TVOCs obtained for each contaminant (pattern) when plants were not present. In scenario two, the module with the plants was placed inside the chamber (separately for the five plant species). The duration of each test was 3 days and the TVOCs values were recorded at $0.25 \mathrm{~h}, 1 \mathrm{~h}, 5 \mathrm{~h}$, and $72 \mathrm{~h}$ from the beginning of the test (addition of the contaminant). In scenario one, the contaminants were added to the chamber with a micropipette until reaching TVOCs values slightly over $3 \mathrm{mg} / \mathrm{m}^{3}$, the limit established by Spanish regulations (UNE 171330-2:2014) to be considered in the 'discomfort range'. Then, 
the same volume of contaminants was added in scenario two. The chamber was sealed to avoid any loss or exchange of gases with the outside.

Three tests were carried out in each scenario for each combination of species and contaminants ( 3 replications $\times 5$ species $\times 2$ contaminants). To determine the efficiency of the species, the percentage of reduction of the contaminant concentration was calculated, considering the TVOCs value reached by each contaminant in the empty chamber as the reference. Therefore, the TVOCs reduction (\%) was calculated as follows for each time (from the introduction of the contaminant):

$$
\% R(n)=100 \cdot\left(\operatorname{TVOCs}(n)_{0}-\operatorname{TVOCs}(n)\right) / \operatorname{TVOCs}(n)_{0}
$$

where $\% \mathrm{R}(\mathrm{n})$ is the reduction (\%) of TVOCs obtained over the TVOCs average value with no vegetation inside the chamber at the same time (n); (n) is the time in hours since the contaminant is released in the chamber until the measure of the TVOCs value; TVOCs(n) is the average TVOCs value at time (n) in the chamber without vegetation; TVOCs(n) is the average TVOCs value at time (n) in the chamber with the living wall module inside.

Immediately after the tests, the total leaf area $\left(\mathrm{cm}^{2} \cdot\right.$ plant $\left.^{-1}\right)$ was determined for each plant species using a leaf area meter LI-3100 (Li-Cor, NE, USA), and the fresh and dry weight of the plants was measured with a precision balance D-6200 CB (I.C.T, S.L., La Rioja, Spain).

Table 1 shows the instruments used during the research with their respective descriptions.

Table 1. Instruments used during the research.

\begin{tabular}{|c|c|c|}
\hline Equipment & Model & Description \\
\hline HOBO & $\begin{array}{c}\text { Pro Temp-HR U23-001 (Onset Computer Corp., } \\
\text { Bourne, MA, USA) }\end{array}$ & $\begin{array}{l}\text { Operation range: } 0 \text { to } 100 \% \mathrm{RH},-40^{\circ} \text { to } 70^{\circ} \mathrm{C} \text {. } \\
\text { Accuracy: } \\
\pm 2.5 \% \text { from } 10 \% \text { to } 90 \% \mathrm{RH} \text { typical to a maximum of } \\
\pm 3.5 \% \text { including hysteresis at } 25^{\circ} \mathrm{C}\left(77^{\circ} \mathrm{F}\right) ; \text { below } 10 \% \\
\text { and above } 90 \% \pm 5 \% \text { typical }\end{array}$ \\
\hline Grow lamp & $\begin{array}{l}\text { A CF-UT01 LED (Panda Grow, } \\
\text { Shenzhen, China) }\end{array}$ & $\begin{array}{l}\text { Voltage: } 110 \mathrm{~V} / 220 \mathrm{~V} . \\
\text { Lamp Luminous Flux }(\mathrm{lm}): 5000 \\
\text { Spectrum: } 560-780 \mathrm{~nm}\end{array}$ \\
\hline Portable fan & CAVN QY072-EU & $5000 \mathrm{mAh}$ \\
\hline Gas detector & PCE-VOC 1 (PCE Ibérica S.L., Albacete, Spain) & $\begin{array}{l}\text { Operation range TVOC: } 0.00 \text { to } 9.99 \mathrm{mg} / \mathrm{m}^{3} \\
\text { Accuracy TVOC: } \pm 5 \% \text { of full scale }\end{array}$ \\
\hline Leaf area meter & LI-3100 (Li-Cor, NE, USA) & $\begin{array}{c}\text { Resolution: } 1 \mathrm{~mm} \times 1 \mathrm{~mm} \\
\text { Accuracy: } \\
10 \mathrm{~cm}^{2}(+1 \%) ; 5 \mathrm{~cm}^{2}(+2 \%) ; 1 \mathrm{~cm}^{2}(+5 \%) ; 0.5 \mathrm{~cm}^{2}(+7 \%) . \\
\text { Precision was determined at the } 99 \% \text { level with } \\
\text { irregular-shaped complex objects. }\end{array}$ \\
\hline Precision balance & D-6200 CB (I.C.T, S.L., La Rioja, Spain) & $\begin{array}{c}\text { Weighing capacity: } 6200 \mathrm{~g} \\
\text { Accuracy: } \\
0.1 \mathrm{~g}\end{array}$ \\
\hline
\end{tabular}

\subsection{Data Treatment and Statistical Analysis}

Two General Linear Models (GLM) were carried out to compare (1) the efficiency of the five species between them for each contaminant, and (2) the efficiency of each species between n-hexane and formaldehyde. In both cases, this is done taking into account the percentage reduction of TVOCs with respect to the pattern of the n-hexane and formaldehyde in the test without plants, at different times $(0.25 \mathrm{~h}, 1 \mathrm{~h}, 5 \mathrm{~h}, 72 \mathrm{~h})$. The variables complied with a normal distribution and with homoscedasticity. Statistical analyses (ANOVA and LSD tests) were performed using Statgraphics Centurion 18 Version 18.1.12. 


\section{Results}

Table 2 shows the main parameters obtained for the five plant species studied at the end of each test. S. wallisii was the species with more biomass, followed by T. pallida. Conversely, F. pumila and P. hederaceum presented a lower development of the vegetation.

Table 2. Total biomass in the living wall (fresh and dry weight), percentage of water, fresh weight media per plant, and leaf area by each plant species exposed to $n$-hexane and formaldehyde.

\begin{tabular}{|c|c|c|c|c|c|}
\hline Plant Parameters & S. wallisii & P. hederaceum & F. pumila & T. pallida & C. comosum \\
\hline Fresh weight (g) & 545.30 & 103.50 & 61.60 & 355.10 & 162.10 \\
\hline Aerial part & 351.10 & 74.90 & 36.70 & 336.70 & 97.30 \\
\hline Roots & 194.20 & 28.60 & 24.90 & 18.40 & 64.80 \\
\hline Dry weight (g) & 72.60 & 12.80 & 14.30 & 23.00 & 11.90 \\
\hline Aerial part & 44.30 & 9.50 & 9.30 & 21.00 & 6.60 \\
\hline Roots & 28.30 & 3.30 & 5.00 & 2.00 & 5.30 \\
\hline \% Water & 86.69 & 87.63 & 76.79 & 93.52 & 92.66 \\
\hline Aerial part & 87.38 & 87.32 & 74.66 & 93.76 & 93.22 \\
\hline Roots & 85.43 & 88.46 & 79.92 & 89.13 & 91.82 \\
\hline $\begin{array}{l}\text { Fresh weight per } \\
\text { plant }(\mathrm{g})\end{array}$ & $181.77 \pm 34.75$ & $17.25 \pm 10.83$ & $10.27 \pm 1.42$ & $59.18 \pm 17.26$ & $27.02 \pm 4.31$ \\
\hline $\begin{array}{l}\text { Total leaf area } \\
\qquad\left(\mathrm{cm}^{2}\right)\end{array}$ & 6306.70 & 729.60 & 1418.40 & 2931.40 & 1904.30 \\
\hline $\begin{array}{l}\text { Mean area per leaf } \\
\qquad\left(\mathrm{cm}^{2}\right)\end{array}$ & 18.33 & 18.71 & 31.52 & 16.75 & 9.24 \\
\hline $\begin{array}{c}\text { Total number of } \\
\text { leaves }\end{array}$ & 344 & 39 & 45 & 175 & 206 \\
\hline
\end{tabular}

The tests were first performed with the chamber without the living wall, in order to obtain the baseline to compare with the tests with plants. The TVOCs maximum values for n-hexane and formaldehyde were $3.35 \mathrm{mg} / \mathrm{m}^{3}$ and $3.69 \mathrm{mg} / \mathrm{m}^{3}$, respectively (Table 3).

Table 3. Average \pm standard deviation of the TVOCs values $\left(\mathrm{mg} / \mathrm{m}^{3}\right)$ recorded for $\mathrm{n}$-hexane and formaldehyde at different times from the introduction of the contaminant.

\begin{tabular}{|c|c|c|c|c|c|c|}
\hline Contaminant & $\begin{array}{c}0.25 \mathrm{~h} \\
\left(\mathrm{mg} / \mathrm{m}^{3}\right)\end{array}$ & $\begin{array}{c}1 \mathrm{~h} \\
\left(\mathrm{mg} / \mathrm{m}^{3}\right)\end{array}$ & $\begin{array}{c}5 \mathrm{~h} \\
\left(\mathrm{mg} / \mathrm{m}^{3}\right)\end{array}$ & $\begin{array}{c}24 \mathrm{~h} \\
\left(\mathrm{mg} / \mathrm{m}^{3}\right)\end{array}$ & $\begin{array}{c}48 \mathrm{~h} \\
\left(\mathrm{mg} / \mathrm{m}^{3}\right)\end{array}$ & $\begin{array}{c}72 \mathrm{~h} \\
\left(\mathrm{mg} / \mathrm{m}^{3}\right)\end{array}$ \\
\hline n-hexane & $3.14 \pm 0.05$ & $3.19 \pm 0.07$ & $3.13 \pm 0.01$ & $3.35 \pm 0.60$ & $3.30 \pm 0.67$ & $3.34 \pm 0.61$ \\
\hline formaldehyde & $1.96 \pm 0.49$ & $2.46 \pm 0.52$ & $2.69 \pm 0.84$ & $3.59 \pm 0.33$ & $3.69 \pm 0.47$ & $3.69 \pm 0.47$ \\
\hline
\end{tabular}

In addition, the different behaviour of each pollutant is observed for the five plant species. Figure 3 shows that all five plant species are more efficient in reducing TVOCs when exposed to formaldehyde than to n-hexane. Furthermore, the reduction of TVOCs tends to be more homogeneous with the five plant species exposed to formaldehyde.

Table 4 shows the percentage of reduction (\%R) of TVOCs values compared with the average in scenario 1 at the same times. There are some significant differences in the TVOCs reduction percentage between species exposed to $\mathrm{n}$-hexane at $0.25 \mathrm{~h}(p$-value $=0.013)$, at $1 \mathrm{~h}(p$-value $=0.012)$, at $24 \mathrm{~h}(p$-value $=0.043)$, at $48 \mathrm{~h}(p$-value $=0.040)$, none at $5 \mathrm{~h}$, and only for $S$. wallisii and the rest of species (except P. hederaceum) $(p$-value $=0.045)$ at $72 \mathrm{~h}$. In the case of formaldehyde, significant differences were only detected for S. wallisii at $0.25 \mathrm{~h}$ $(p$-value $=0.050)$, at $1 \mathrm{~h}(p$-value $=0.023)$, at $5 \mathrm{~h}(p$-value $=0.033)$, at $24 \mathrm{~h}(p$-value $=0.000)$, at $48 \mathrm{~h}(p$-value $=0.000)$, and at $72 \mathrm{~h}(p$-value $=0.015)$.

Comparing the efficiency within the same species in removing the two contaminants, during the first day, the five species have significant differences in the percentage reduction of TVOCs when exposed to n-hexane compared to formaldehyde, being more efficient in the absorption of the latter. At $48 \mathrm{~h}$, only $S$. wallisii had differences between both contaminants. Only at $72 \mathrm{~h}$ were there no significant differences for any species (Table 3 ). 

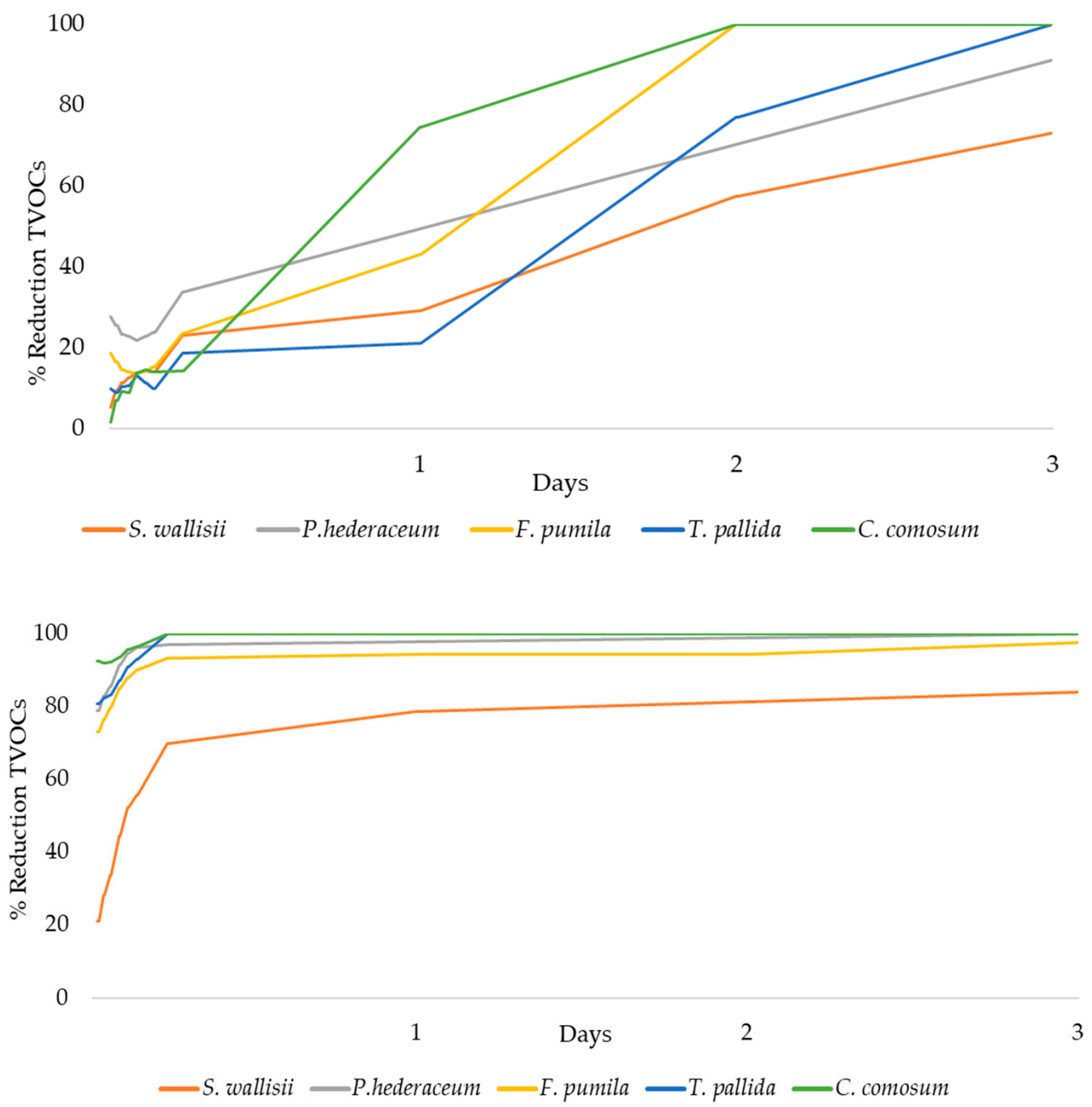

Figure 3. Evolution of the TVOCs reduction percentage for the five plant species exposed during three days to n-hexane (up) and Formaldehyde (down).

Table 4. Analysis of variance between TVOCs reduction percentage of the five species in different time ranges for each contaminant.

\begin{tabular}{cccccccc}
\hline Contaminant & Species & \%R0.25 & \%R1 & \%R5 & \%R24 & \%R48 & \% R72 \\
\hline n-hexane & S. wallisii & $11 \pm 3.6 \mathrm{~b}$ & $14 \pm 4.1 \mathrm{a}$ & $23 \pm 3.2$ & $29 \pm 2.2 \mathrm{~b}$ & $57 \pm 18.6 \mathrm{~b}$ & $73 \pm 24.0 \mathrm{~b}$ \\
& P. hederaceum & $23 \pm 10.7 \mathrm{ab}$ & $24 \pm 10.9 \mathrm{ab}$ & $34 \pm 15.7$ & - & - & $91 \pm 11.2 \mathrm{ab}$ \\
& F. pumila & $15 \pm 10.9 \mathrm{~b}$ & $15 \pm 10.8 \mathrm{a}$ & $24 \pm 9.6$ & $43 \pm 25.1 \mathrm{a}$ & $100 \pm 0.0 \mathrm{a}$ & $100 \pm 0.0 \mathrm{a}$ \\
& T. pallida & $10 \pm 36.8 \mathrm{a}$ & $10 \pm 30.2 \mathrm{~b}$ & $19 \pm 39.5$ & $21 \pm 21.5 \mathrm{~b}$ & $77 \pm 32.6 \mathrm{ab}$ & $100 \pm 0.0 \mathrm{a}$ \\
& C. comosum & $9 \pm 15.4 \mathrm{ab}$ & $14 \pm 17.4 \mathrm{ab}$ & $14 \pm 16.7$ & $65 \pm 0.5 \mathrm{a}$ & $100 \pm 0.0 \mathrm{a}$ & $100 \pm 0.0 \mathrm{a}$ \\
formaldehyde & S. wallisii & $28 \pm 7.9 \mathrm{~b}$ & $56 \pm 10.3 \mathrm{~b}$ & $70 \pm 8.4 \mathrm{~b}$ & $79 \pm 4.6 \mathrm{~b}$ & $81 \pm 4.4 \mathrm{~b}$ & $84 \pm 4.4 \mathrm{~b}$ \\
& P. hederaceum & $83 \pm 3.1 \mathrm{a}$ & $96 \pm 3.6 \mathrm{a}$ & $97 \pm 2.9 \mathrm{a}$ & - & - & $100 \pm 0.0 \mathrm{a}$ \\
& F. pumila & $76 \pm 10.0 \mathrm{a}$ & $90 \pm 3.8 \mathrm{a}$ & $93 \pm 3.6 \mathrm{a}$ & $94 \pm 6.1 \mathrm{a}$ & $94 \pm 6.1 \mathrm{a}$ & $98 \pm 2.7 \mathrm{a}$ \\
& T. pallida & $82 \pm 13.4 \mathrm{a}$ & $93 \pm 5.8 \mathrm{a}$ & $100 \pm 0.0 \mathrm{a}$ & $100 \pm 0.0 \mathrm{a}$ & $100 \pm 0.0 \mathrm{a}$ & $100 \pm 0.0 \mathrm{a}$ \\
& C. comosum & $92 \pm 0.9 \mathrm{a}$ & $96 \pm 0.3 \mathrm{a}$ & $100 \pm 0.0 \mathrm{a}$ & $100 \pm 0.0 \mathrm{a}$ & $100 \pm 0.0 \mathrm{a}$ & $100 \pm 0.0 \mathrm{a}$ \\
\hline
\end{tabular}

\%R1/4: TVOCs reduction at $0.25 \mathrm{~h}$. \%R1: TVOCs reduction at $1 \mathrm{~h}$. \%R5: TVOCs reduction at $5 \mathrm{~h}$. \%R24: TVOCs reduction at $24 \mathrm{~h}$. \%R48: TVOCs reduction at $48 \mathrm{~h}$. \%T72: TVOCs reduction at $72 \mathrm{~h}$. Different small letters in the same column denote significant differences, for the same contaminant, of the percentage reduction of TVOCs between the plant species according to the ANOVA and the LSD Test $(p<0.05)$. 


\section{Discussion}

This study confirms that plants contribute to the improvement of indoor air quality by reducing the concentration of VOCs. The effect is higher the longer the air is in contact with the plants [19]. However, the efficiency in this reduction was different depending on the contaminant and on the species used.

In spite of the difference in the quantity of vegetation, there was not any correlation between the leaf area/fresh weight/dry weight and the reduction of contaminants. Therefore, the differences observed are due to the species tested. The same was also observed in a similar experiment using n-hexane and living walls planted with Nephrolepis exaltata L., comparing the effect of different quantities of vegetation [19].

In general, the five species tested (S. wallisii, P. hederaceum, F. pumila, T. pallida, and C. comosum) were more efficient in reducing the concentration of TVOCs when exposed to formaldehyde than to n-hexane. In fact, most species achieved a 100\% reduction between $5 \mathrm{~h}$ and $24 \mathrm{~h}$ after the introduction of the formaldehyde. Conversely, only two species ( $F$. pumila and C. comosum) attained a $100 \%$ reduction after $48 \mathrm{~h}$ with $\mathrm{n}$-hexane.

These differences in the percent removed depending on the contaminant were also reported by other authors. For example, Wolverton et al. [32] obtained much higher reduction percentages for formaldehyde than for trichloroethylene for the same species. Formaldehyde appears to be efficiently detoxified by oxidation [30] and this mechanism is faster, while n-hexane removal has been reported to be slow, as it is more related to the microorganisms associated with the root system [33].

A different behaviour was also observed depending on the contaminant used when no vegetation was present in the chamber. Although the TVOCs' maximum values for n-hexane and formaldehyde were similar after $72 \mathrm{~h}$, the TVOCs reached high values in less time when using $\mathrm{n}$-hexane than with formaldehyde. This progressive increase of TVOCs with formaldehyde could be one of the factors of the better results obtained in reducing the concentration of the contaminant in the indoor environment.

C. comosum was, among those tested, the most efficient species in reducing the concentration of TVOCs for both contaminants, followed by F. pumila when exposed to n-hexane and T. pallida for formaldehyde. The three of them completely eliminated the VOCs after $72 \mathrm{~h}$. C. comosum has also shown a higher potential for benzene [34] and ethylbenzene [35] removal than other species. T. pallida was considered a very effective plant for the removal of VOCs by other authors too $[28,36]$.

For n-hexane, $P$. hederaceum reduced the concentration of TVOCs faster during the first $5 \mathrm{~h}$, though after that the rate of reduction decreased and this species did not achieve the total removal of the contaminant at $72 \mathrm{~h}$. For formaldehyde, P. hederaceum had similar behaviour to the other species (except $S$. wallisii), nearly eliminating the contaminant after one hour. Both C. comosum and P. hederaceum were catalogued among the species with a higher potential for removing formaldehyde after a review of several studies [37].

S. wallisii was the least efficient by far in reducing both contaminants. Even so, reductions of 73 and $84 \%$ were achieved at $72 \mathrm{~h}$. Other studies also considered S. wallisii as one of the least efficient species in the removal of TVOCs [28,38]. In fact, in a study assessing formaldehyde removal by 20 different herbaceous foliage species, S. wallisii figured in the lower quarter [17].

Although $S$. wallisii had the largest leaf area compared to the other species, this did not influence its efficiency in reducing the concentration of TVOCs for both contaminants. Noor et al. [36] reported that leaf area plays a moderate role in VOC adsorption but is not drastically influential.

It is interesting to highlight that the reduction of VOCs starts instantly, as TVOCs values in the first minutes after releasing the contaminant never reached those obtained when the chamber had no vegetation. Furthermore, the reduction had a much higher rate in the first $15 \mathrm{~min}$, decreasing rapidly over time. This was more evident for the formaldehyde. In fact, for this compound reductions between 76 and $92 \%$ were already obtained in the first $15 \mathrm{~min}$ (except for the case of S. wallisii, which only reduced around 30\%). 
The selection of the species is clearly important to maximise the reduction of VOCs obtained when installing a living wall indoors. Though usually, a living wall integrates several different species, their selection must respond to certain objectives that should combine the aesthetical perspective with practical issues (such as water and light requirements, maintenance, etc.) in order to maximise the benefits obtained. Thus, one way to address variability in VOC abatement efficiency between species is through the design of living walls with a combination of different species.

In a living wall system, not only the plants are responsible for VOC removal. Additionally, the substrate or soil employed will have a part, as rhizosphere microbial activity is an important mechanism for VOC reduction $[33,39]$, as well as the direct adsorption of VOCs into the soils [40].

\section{Conclusions}

This study confirmed the effect that a living wall has on removing VOCs. However, the removal efficiency changed depending on the contaminant used. It was clear that the species employed were more efficient in removing formaldehyde than n-hexane. $C$. comosum exhibited the best results while $S$. wallisii was the least efficient.

The main limitation of this study is the use of a small and sealed chamber, given that it is difficult to extrapolate the results. Therefore, carrying out additional experiments in 'real life' conditions is recommended. In addition, there is still a need for further studies about this topic involving other plant species and assessing the specific mechanisms or processes involved in the VOCs removal. The influence of other variables such as environmental conditions, lighting patterns, or substrates employed are also worthy to be considered for future studies.

Author Contributions: Conceptualisation, G.P.S.-C. and L.P.-U.; Methodology, L.P.-U.; Validation, L.P.-U.; Formal analysis, G.P.S.-C.; Investigation, G.P.S.-C. and L.P.-U.; Resources, L.P.-U.; Writingoriginal draft preparation, G.P.S.-C.; Writing-review and editing, L.P.-U.; Supervision, L.P.-U.; Project administration, L.P.-U.; Funding acquisition, L.P.-U. All authors have read and agreed to the published version of the manuscript.

Funding: This research was funded by the Andalusian Regional government (Junta de Andalucía, Spain) in the 2018 call for Research projects for universities and qualified public research entities as agents of the Andalusian Knowledge System, within the scope of the Andalusian Plan of Research, development and innovation 2020, grant number P18-TP-1657.

Institutional Review Board Statement: Not applicable.

Informed Consent Statement: Not applicable.

Data Availability Statement: All data obtained were reported in the article.

Acknowledgments: We acknowledge Rafael Fernández-Cañero, Antonio Franco-Salas of the Urban Greening and Biosystems Engineering research group and Antonio José Fernández-Espinosa and Sabina Rossini-Oliva of the Environmental Analytic Chemistry research group of the University of Seville for their support and availability during the experimental development of this study.

Conflicts of Interest: The authors declare no conflict of interest. The funders had no role in the design of the study; in the collection, analyses, or interpretation of data; in the writing of the manuscript, or in the decision to publish the results.

\section{References}

1. Langer, S.; Ramalho, O.; Derbez, M.; Ribéron, J.; Kirchner, S.; Mandin, C. Indoor environmental quality in French dwellings and building characteristics. Atmos. Environ. 2016, 128, 82-91. [CrossRef]

2. Fisk, W.J. Health and productivity gains from better indoor environments and their relationship with building energy efficiency. Annu. Rev. Energy Environ. 2000, 25, 537-566. [CrossRef]

3. Ole, F.P. What is IAQ? Indoor Air 2006, 16, 328-334. [CrossRef]

4. Yu, C.W.F.; Kim, J.T. Photocatalytic oxidation for maintenance of indoor environmental quality. Indoor Built Environ. 2013, 22, 39-51. [CrossRef] 
5. Sakai, K.; Norbäck, D.; Mi, Y.; Shibata, E.; Kamijima, M.; Yamada, T.; Takeuchi, Y. A comparison of indoor air pollutants in Japan and Sweden: Formaldehyde, nitrogen dioxide, and chlorinated volatile organic compounds. Environ. Res. 2004, $94,75-85$. [CrossRef]

6. Shrubsole, C.; Dimitroulopoulou, S.; Foxall, K.; Gadeberg, B.; Doutsi, A. IAQ guidelines for selected volatile organic compounds (VOCs) in the UK. Build. Environ. 2019, 165, 106382. [CrossRef]

7. Rösch, C.; Kohajda, T.; Röder, S.; von Bergen, M.; Schlink, U. Relationship between sources and patterns of VOCs in indoor air. Atmos. Pollut. Res. 2014, 5, 129-137. [CrossRef]

8. Park, J.S.; Ikeda, K. Variations of formaldehyde and VOC levels during 3 years in new and older homes. Indoor Air 2006, 16, 129-135. [CrossRef] [PubMed]

9. Raw, G.J.; Coward, S.K.D.; Brown, V.M.; Crump, D.R. Exposure to air pollutants in English homes. J. Expo. Anal. Environ. Epidemiol. 2004, 14, 85-94. [CrossRef]

10. Guo, H.; Kwok, N.H.; Cheng, H.R.; Lee, S.C.; Hung, W.T.; Li, Y.S. Formaldehyde and volatile organic compounds in Hong Kong homes: Concentrations and impact factors. Indoor Air 2009, 19, 206-217. [CrossRef]

11. Salthammer, T.; Mentese, S.; Marutzky, R. Formaldehyde in the indoor environment. Chem. Rev. 2010, 110, 2536-2572. [CrossRef]

12. Lai, H.K.; Kendall, M.; Ferrier, H.; Lindup, I.; Alm, S.; Hänninen, O.; Jantunen, M.; Mathys, P.; Colvile, R.; Ashmore, M.R.; et al. Personal exposures and microenvironment concentrations of PM 2.5, VOC, $\mathrm{NO}_{2}$ and $\mathrm{CO}$ in Oxford, UK. Atmos. Environ. 2004, 38, 6399-6410. [CrossRef]

13. Srivastava, P.K.; Pandit, G.G.; Sharma, S.; Mohan Rao, A.M. Volatile organic compounds in indoor environments in Mumbai, India. Sci. Total Environ. 2000, 255, 161-168. [CrossRef]

14. Torpy, F.; Clements, N.; Pollinger, M.; Dengel, A.; Mulvihill, I.; He, C.; Irga, P. Testing the single-pass VOC removal efficiency of an active green wall using methyl ethyl ketone (MEK). Air Qual. Atmos. Health 2018, 11, 163-170. [CrossRef] [PubMed]

15. Gawrońska, H.; Bakera, B. Phytorremediation of particulate matter from indoor air by Chlorophytum comosum L. plants. Air Qual. Atmos. Health 2015, 8, 265-272. [CrossRef] [PubMed]

16. Dela Cruz, M.; Christensen, J.H.; Thomsen, J.D.; Müller, R. Can ornamental potted plants remove volatile organic compounds from indoor air?-A review. Environ. Sci. Pollut. Res. 2014, 21, 13909-13928. [CrossRef] [PubMed]

17. Kim, K.J.; Jeong, M., II; Lee, D.W.; Song, J.S.; Kim, H.D.; Yoo, E.H.; Jeong, S.J.; Han, S.W.; Kays, S.J.; Lim, Y.W.; et al. Variation in formaldehyde removal efficiency among indoor plant species. HortScience 2010, 45, 1489-1495. [CrossRef]

18. Suárez-Cáceres, G.P.; Fernández-Cañero, R.; Fernández-Espinosa, A.J.; Rossini-Oliva, S.; Franco-Salas, A.; Pérez-Urrestarazu, L. Volatile organic compounds removal by means of a felt-based living wall to improve indoor air quality. Atmos. Pollut. Res. 2021, 12, 224-229. [CrossRef]

19. Pérez-Urrestarazu, L.; Fernández-Cañero, R.; Franco-Salas, A.; Egea, G. Vertical Greening Systems and Sustainable Cities. J. Urban Technol. 2015, 22, 65-85. [CrossRef]

20. Irga, P.J.; Pettit, T.; Irga, R.F.; Paull, N.J.; Douglas, A.N.J.; Torpy, F.R. Does plant species selection in functional active green walls influence VOC phytoremediation efficiency? Environ. Sci. Pollut. Res. 2019, 26, 12851-12858. [CrossRef]

21. Pérez-Urrestarazu, L.; Fernández-Cañero, R.; Campos-Navarro, P.; Sousa-Ortega, C.; Egea, G. Assessment of perlite, expanded clay and pumice as substrates for living walls. Sci. Hortic. 2019, 254, 48-54. [CrossRef]

22. Parseh, I.; Teiri, H.; Hajizadeh, Y.; Ebrahimpour, K. Phytoremediation of benzene vapors from indoor air by Schefflera arboricola and Spathiphyllum wallisii plants. Atmos. Pollut. Res. 2018, 9, 1083-1087. [CrossRef]

23. Wolverton, B.; Wolverton, J. Plants and soil microorganisms: Removal of formaldehyde, xylene, and ammonia from the indoor environment. J. Miss. Acad. Sci. 1993, 38, 11-15.

24. Sadhana, K.; Sudhadevi, P.K. Evaluation of susceptibility levels of different species/varieties of philodendron to air pollution. Adv. Life Sci. 2016, 5, 1834-1839.

25. Keever, G.J.; Cobb, G.S.; Stephenson, J.C. Interior performance of temperate zone landscape plants. J. Environ. Hortic. 1988, 6, 84-87. [CrossRef]

26. Pérez-Urrestarazu, L.; Fernández-Cañero, R.; Franco, A.; Egea, G. Influence of an active living wall on indoor temperature and humidity conditions. Ecol. Eng. 2016, 90, 120-124. [CrossRef]

27. Cardoso-Meireles, J.R.; Marcílio-Cerqueira, E.M. Use of the micronucleus test on Tradescantia (Trad-MCN) to evaluate the genotoxic effects of air pollution. In Air Pollution: New Developments; Moldoveanu, A.M., Ed.; IntechOpen: Rijeka, Croatia, 2011; Volume 1, pp. 245-262. ISBN 978-953-307-527-3.

28. Yang, D.S.; Pennisi, S.V.; Son, K.-C.C.; Kays, S.J. Screening indoor plants for volatile organic pollutant removal efficiency. HortScience 2009, 44, 1377-1381. [CrossRef]

29. Soreanu, G.; Dixon, M.; Darlington, A. Botanical biofiltration of indoor gaseous pollutants-A mini-review. Chem. Eng. J. 2013, 229, 585-594. [CrossRef]

30. Giese, M.; Bauer-Doranth, U.; Langebartels, C.; Sandermann, H., Jr. Detoxification of formaldehyde by the spider plant (Chlorophytum comosum L.) and by soybean (Glycine max L.) cell-suspension cultures. Plant Physiol. 1994, 104, 1301-1309. [CrossRef] [PubMed]

31. Mølhave, L.; Clausen, G.; Berglund, B.; De Ceaurriz, J.; Kettrup, A.; Lindvall, T.; Maroni, M.; Pickering, A.C.; Risse, U.; Rothweiler, H.; et al. Total volatile organic compounds (TVOC) in indoor air quality investigations. Indoor Air 1997, 7, 225-240. [CrossRef] 
32. Wolverton, B.C.; Johnson, A.; Bounds, K. Interior Landscape Plants for Indoor Air Pollution Abatement; Hancock: Saint Louis, MS, USA, 1989

33. Wood, R.A.; Orwell, R.L.; Tarran, J.; Torpy, F.; Burchett, M. Potted-plant/growth media interactions and capacities for removal of volatiles from indoor air. J. Hortic. Sci. Biotechnol. 2002, 77, 120-129. [CrossRef]

34. Sriprapat, W.; Thiravetyan, P. Efficacy of ornamental plants for benzene removal from contaminated air and water: Effect of plant associated bacteria. Int. Biodeterior. Biodegrad. 2016, 113, 262-268. [CrossRef]

35. Sriprapat, W.; Suksabye, P.; Areephak, S.; Klantup, P.; Waraha, A.; Sawattan, A.; Thiravetyan, P. Uptake of toluene and ethylbenzene by plants: Removal of volatile indoor air contaminants. Ecotoxicol. Environ. Saf. 2014, 102, 147-151. [CrossRef] [PubMed]

36. Noor, H.M.; Ahmad, H. Native ornamental potted plants for sustainable improvement of indoor air quality. Int. J. Appl. Agric. Sci. 2020, 6, 44-51. [CrossRef]

37. Bandehali, S.; Miri, T.; Onyeaka, H.; Kumar, P. Current state of indoor air phytoremediation using potted plants and green walls. Atmosphere 2021, 12, 473. [CrossRef]

38. Liu, Y.J.; Mu, Y.J.; Zhu, Y.G.; Ding, H.; Crystal Arens, N. Which ornamental plant species effectively remove benzene from indoor air? Atmos. Environ. 2007, 41, 650-654. [CrossRef]

39. Orwell, R.L.; Wood, R.L.; Tarran, J.; Torpy, F.; Burchett, M.D. Removal of benzene by the indoor plant/substrate microcosm and implications for air quality. Water Air Soil Pollut. 2004, 157, 193-207. [CrossRef]

40. Ruiz, J.; Bilbao, R.; Murillo, M.B. Adsorption of different VOC onto soil minerals from gas phase: Influence of mineral, type of VOC, and air humidity. Environ. Sci. Technol. 1998, 32, 1079-1084. [CrossRef] 